\title{
EDITORIAL
}

\section{MULTINATIONAL OPERATIONS AND THE LAW - GREAT EXPECTATIONS, GREAT RESPONSIBILITIES}

Since time immemorial, belligerents have formed alliances to defeat a common enemy, to conquer territory, or to defend it. Alliances between states have sought not only to fulfil an offensive objective, but also to deter attacks and ensure stability and peace in international relations. In addition to the military advantage they may offer, coalitions or alliances may appear to give additional legitimacy to the cause at stake.

In modern times, the various systems of alliance have failed to ensure international peace and security - the two World Wars are a painful testimony to this, with conflicts between two states quickly escalating into global war. In 1945, the United Nations (UN) Charter prohibited the use of force in international relations (without prejudice, however, to the 'inherent' right of each state to use force in legitimate self-defence). The Charter also set up a collective security mechanism, whereby each state accepts that the security of one is the concern of all and therefore commits to a collective response to threats to and breaches of the prohibition to use force. This mechanism specifically allows states to use force collectively in situations where international peace and security are threatened. However, this system is certainly not perfect, as it reflects a compromise between collective response and the respect for states' sovereignty, in addition to embedding a special role for the victorious powers emerging from the Second World War through the possibility of vetoing the UN Security Council's resolutions.

Whether undertaken under UN command and control or by a regional organisation (such as the North Atlantic Treaty Organisation, NATO) acting with the authorisation of the UN, multinational operations are a common phenomenon today and, in the experience of many states, the only type of military operations they have recently conducted.

Today, multinational forces may become involved in hostilities and be called upon to use force against organised armed groups. Sometimes, they receive the explicit mandate to counter the threat emanating from such groups. ${ }^{1}$ Given the changing landscape of warfare and of international relations, a number of legal and humanitarian challenges related to the engagement of multinational forces remain to be solved. This issue of the Review will expose these new challenges and bring answers to these questions.

\section{What is at stake?}

In an ever-changing environment, multinational operations are now deployed with more complex, multidimensional mandates. Before engaging in an operation, states 
and their militaries need to know what their legal status will be in the context, and what rules will apply, for example, when they use force against local insurgents. What protection does international law give them? What training needs to be given to troops before their deployment, and how can they be prepared for the growing multiplicity of tasks they will face in the field? According to what standards should they treat people in their power, and when is it lawful to hand such individuals over to local authorities?

The allocation of responsibility between states participating in operations, international organisation(s) and the host state has to be as clear-cut as possible. Even if their capacities do not always match their responsibilities, multinational forces will be exposed to public scrutiny and their troops will be expected to show exemplary conduct. The measures taken by UN peacekeeping missions, in particular, to ensure that the parties to a conflict comply with international humanitarian law (IHL) may also play an essential role in improving the plight of the civilian population.

Leaving aside the study of traditional military alliances, this issue of the Review focuses mainly on the following types of multinational operations: first, UN-led peace operations (such as the UN Operation in Côte d'Ivoire, the UN Stabilisation Mission in Haiti, or the UN Interim Administration Mission in Kosovo); second, operations authorised by the UN but carried out by other actors, such as a regional organisation or a coalition of states (such as the African Union Mission in Somalia (AMISOM), or the International Security Assistance Force (ISAF) in Afghanistan); and third, hybrid or co-led operations (such as the African Union-United Nations Operations in Darfur (UNAMID)). ${ }^{2}$ A number of legal and operational challenges remain outstanding across all types of multinational operations.

\section{The evolution of United Nations peacekeeping operations}

One cannot discuss the evolution of multinational operations without looking first and foremost at UN peacekeeping operations.

Since 1948, the UN has launched 69 peacekeeping operations, ${ }^{3}$ whose mandates have varied greatly over time depending on the conditions on the ground and on the global context, as explained by Ronald Hatto in his opening article in this edition of the Review. The first formally named 'peacekeeping mission' was the First UN Emergency Force (UNEF I), established in November 1956 between Egypt and Israel during the Suez Crisis. Between then and 1989, the UN launched sixteen peacekeeping operations mostly under this traditional form of 'interposition forces'.

1 See, for instance, SC Res. 2098, 28 March 2013, para. 9, authorising the Force Intervention Brigade in the Democratic Republic of the Congo (DRC) to, inter alia, neutralise armed groups and 'reduce the threat posed by armed groups to state authority and civilian security in eastern DRC'.

2 Established by SC Res. 1769, 31 July 2007, UNAMID incorporated former AMIS personnel into its structure.

3 See United Nations Department of Peacekeeping Operations, 'Peacekeeping Fact Sheet', 31 May 2014, available at: www.un.org/en/peacekeeping/resources/statistics/factsheet.shtml. All internet references were last accessed in June 2014. 
They consisted of military observers, unarmed or lightly armed, mandated to monitor and report on ceasefires or peace agreements.

The end of the Cold War modified the environment in which peacekeeping forces operated and prompted a move towards more complex, multidimensional missions mandated to lay down the foundations of lasting peace in certain contexts. ${ }^{4}$ In addition to the traditional military and police components, such missions have included increasingly important civilian components (legal experts, deminers, electoral observers, humanitarian workers, economists and so on).

The first four decades of multinational operations saw the UN engage in numerous challenging contexts 'when there was no peace to keep'5 or when peace was extremely fragile, sometimes resulting in terrible failures, as in Somalia, Rwanda and Bosnia. This led to what Ronald Hatto describes in his article as a 'temporary standby' in UN peacekeeping operations, or at least a decline in their ambitions until 1999. However, the realisation that the UN was the only organisation able to carry out operations in virtually any area of the world brought UN peacekeeping back to the fore and, since June 1999, the number of multinational operations under UN command and control has steadily increased, with twenty peace operations launched between June 1999 and April $2014 .{ }^{6}$

Today there are sixteen UN peacekeeping operations around the world, to which 122 countries are contributing military, police and civilian personnel. India, Bangladesh and Pakistan are the lead troop-contributing countries. As of March 2014, UN peacekeeping operations were composed of 97,518 uniformed personnel (police and military personnel armed and unarmed) and 16,979 civilian personnel, as well as other additional staff (UN volunteers and so on). Their total annual budget amounts to $\$ 7.9$ billion for the period 2013-2014. ${ }^{7}$ All UN peacekeeping operations considered, the UN commands the second-largest number of deployed troops in the world after the United States.

In the opening interview of this issue of the Review, General Babacar Gaye, Military Adviser for UN Peacekeeping Operations in New York, brings an operational perspective of the challenges faced by peacekeepers around the world.

\section{Increasingly robust, multidimensional and protection-oriented missions}

Multinational operations continue to evolve as a consequence of the complexity of the tasks at hand.

4 These peace-building missions have included the organisation of elections, the disarmament, demobilisation and reintegration of former combatants, and the restoration of the rule of law, to name only a few. See United Nations, 'Peace and Security', available at: www.un.org/en/globalissues/ peacesecurity/.

5 'We tried to keep peace and apply the rules of peacekeeping when there was no peace to keep': Kofi Annan, Report, November 1999.

6 Five of those were deployed between June 1999 and July 2000, in Kosovo, Sierra Leone, East Timor, the DRC and Ethiopia/Eritrea.

7 See above note 3 . 
UN peacekeeping missions have evolved from small observer missions to increasingly robust operations, as illustrated most recently by the Force Intervention Brigade set up under the UN Stabilisation Mission in the Democratic Republic of the Congo (MONUSCO). On 28 March 2013, following intense conflicts in the North Kivu region of the Democratic Republic of the Congo (DRC), the UN Security Council adopted Resolution 2098 creating a Force Intervention Brigade tasked 'with the responsibility of neutralizing armed groups ... and the objective of contributing to reducing the threat posed by armed groups to state authority and civilian security in eastern DRC and to make space for stabilization activities'. ${ }^{8}$ Not only is this the first time the UN has set up a force with a specifically offensive-rather than defensive-mandate, with the aim of improving the protection of civilians, but it also illustrates the development of interactions between the military components of multinational forces and an increasing number of civilian partners, such as experts in the organisation of elections.

The ever more 'all-encompassing' mandates under Chapter VII of the UN Charter have included over the years a specific mandate to protect civilians under imminent threat of physical violence. ${ }^{9}$ As Haidi Willmot and Scott Sheeran explain in this issue of the Review, the concept of 'protection of civilians' has evolved over time and is understood differently by the humanitarian, human rights and peacekeeping communities. These various perspectives have to be reconciled in order to guarantee an efficient fulfilment of this mandate.

The multidimensional aspect of peacekeeping has been reinforced over these last few years, and this has led the UN to progressively realise that it cannot efficiently deal with the increasingly wide range of peace-building activities on its own and that it has to work in close collaboration with the growing number of other, increasingly important, humanitarian actors: the African Union, the European Union (EU), NATO and other regional and sub-regional organisations, as well as private actors and non-governmental organisations. In this issue of the Review, Jeremie Labbe and Arthur Boutellis explore what they call 'peace operations by proxy', in which UN personnel are supported by or support national, regional or multinational non-UN partners. For instance, UN Security Council Resolution 2100 authorised French troops to intervene in Mali to support MINUSMA when it was placed 'under imminent and serious threat'. In Somalia, the UN supported AMISOM. Labbe and Boutellis analyse the consequent tension between peacekeeping and humanitarian action; they also examine the legal and policy impacts on humanitarian action of these UN partnerships with non-UN actors, and put forward some solutions to diminish these impacts.

8 See above note 1.

9 The first UN operation with an explicit protection of civilians mandate was the UN Mission in Sierra Leone (UNAMSIL), established in October 1999. In 2000, the Brahimi Report found that, regardless of the nature of their mandate, 'all peacekeepers - troops or police - who witness violence against civilians should be presumed to be authorized to stop it, within their means, in support of basic United Nations principles and, as stated in the report of the Independent Inquiry on Rwanda, consistent with "the perception and the expectation of protection created by [an operation's] very presence" (see S/1999/1257, p. 51)'. See United Nations, Report of the Panel on United Nations Peace Operations, UN Doc. A/55/305S/2000/809, 21 August 2000, available at: www.un.org/en/ga/search/view_doc.asp?symbol=A/55/305. 


\section{Legal challenges}

The above elements highlight the need for the international community to develop a coherent legal framework that embraces the complexity of such operations. When it comes to the law, despite extensive literature on multinational operations, much remains to be clarified. In 2011, the International Committee of the Red Cross (ICRC) 'submitted that a number of legal questions relating to peace operations remain unsettled and, in light of their importance and consequences, deserve to be closely examined'. ${ }^{10}$ The ICRC based this observation on its extensive experience and interaction with various multinational forces on the ground over the years: today, it operates in all contexts where UN peacekeeping forces are deployed. ${ }^{11}$ It was present in Rwanda during Operation Turquoise, in Kosovo when the NATO mission in Kosovo (KFOR) deployed, in Cote d'Ivoire during Operation Unicorn, and more recently, in Mali when Operation Hydra deployed. It has shared the same operational environment with ISAF forces in Afghanistan, AMISOM forces in Somalia, and the International Force for East Timor (INTERFET), among others.

\section{The legal status of UN peacekeepers}

The increasing number of partnerships and of troop-contributing countries enables wide-ranging activities, but it does not come without difficulties. In this issue of the Review, Dieter Fleck discusses the particular challenge posed by the determination of the legal status of UN peacekeepers, analysing in detail the shortcomings of the 1994 UN Convention on the Safety of UN and Associated Personnel. This document criminalises attacks against UN peacekeepers who are not 'engaged as combatants against organized armed forces and to which the law of international armed conflicts applies' (Art. 2(2)) - a sentence that has triggered intense debate among legal scholars. Dieter Fleck further discusses the ways in which Status of Forces Agreements (SOFAs) and Status of Mission Agreements (SOMAs) can help in better defining the status, rights and obligations of UN peacekeepers.

\section{Applicability of international humanitarian law to multinational operations}

The applicability of IHL to multinational forces acting under Chapter VII has long been subject to debate. Indeed, in the past, some authors considered that, since these

10 'International Humanitarian Law and the Challenges of Contemporary Armed Conflicts', official working document of the $31^{\text {st }}$ International Conference of the Red Cross and Red Crescent, Geneva, 28 November1 December 2011, p. 30, available at: www.icrc.org/eng/assets/files/red-cross-crescent-movement/31stinternational-conference/31-int-conference-ihl-challenges-report-11-5-1-2-en.pdf.

11 Today UN peacekeeping missions are deployed in the Central African Republic, Western Sahara, Mali, Haiti, the DRC, Afghanistan, Darfur, Cyprus, Lebanon, Abyei, Kosovo, Liberia, South Sudan, India and Pakistan, Cote d'Ivoire and the Middle East (military observer mission). See United Nations Peacekeeping Operations, 'Fact Sheet', 31 May 2014, available at: www.un.org/en/peacekeeping/documents/bnote0514. pdf. The ICRC is currently operational in all of these contexts. 
forces were representing the majority of states fighting for a 'just cause', they should not be considered as parties to armed conflicts bound by IHL.

However, as Tristan Ferraro explains in his article, in discussing the applicability of IHL to multinational operations, one must clearly distinguish between jus ad bellum (the rules related to the authorisation or prohibition to use armed force under public international law, i.e. the reason for waging a war) and jus in bello (the body of law regulating the conduct of hostilities between belligerents and protecting the persons affected by the armed conflict). Whatever the justification of the war or its underlying 'just cause', all belligerents are equally bound to respect certain rules in order to ensure a minimum of humanity in war. Today there seems to be a general consensus that is it possible that multinational forces can become parties to an armed conflict. Frederic Naert, Katarina Grenfell and Peter Olson further offer some insights as to the EU, UN and NATO perspectives on the issue of applicability and application of IHL to multinational forces.

\section{Legal classification of situations involving multinational forces}

The legal classification of a situation involving a multinational force-that is, whether the legal frame of reference should be that of international armed conflicts, non-international armed conflicts, or domestic law and human rights law - raises complex questions. As the debate between Eric David and Ola Engdahl in this issue illustrates, the views diverge on the implications of the involvement of a multinational force for the classification of a situation. This determination is key to the identification of the legal framework applicable to each and every situation.

\section{Interoperability and multinational operations}

'There is only one thing worse than fighting with allies, and that is fighting without them.'12 This quote by Winston Churchill, speaking about the Anglo-American relationship during the Second World War, reflects the ambivalence of multinational military operations: the advantage of combining forces to overcome an enemy, but also the difficulty of working with foreign troops, who deploy different materiel, come from different cultures, speak different languages, may pursue different political objectives and are bound by different legal obligations.

Indeed, even when the applicability of IHL in a multinational operation is established, and the situation is classified, states will not all be bound by the same international obligations. While the Geneva Conventions have been nearly universally ratified, this is not true for all treaties. States may thus have differing legal obligations under IHL and international human rights law (IHRL) in times of armed conflict, as well as differing interpretations and implementations of such 
obligations. For example, they may have different rules of engagement, chains of command and stances on the extraterritorial applicability of human rights law. The coordination of forces subject to different legal obligations is a crucial challenge for multinational forces. The means to ensure a certain legal interoperability between troops is explored by Marten Zwanenburg in this issue of the Review.

\section{Detention by multinational forces}

Multinational forces today are recurrently involved in the detention of individuals, but they may also themselves be captured in the course of an operation. Two issues stand out as particular challenges: the procedural safeguards for detention in noninternational armed conflicts, and the transfer of detainees to local authorities or to other troop-contributing countries.

States have diverging views as to whether persons deprived of their liberty are protected only by IHL or also by IHRL in times of armed conflict. There is also some disagreement as to the origins of the legal basis for detaining or interning individuals. Moreover, states have diverging interpretations of the principle of nonrefoulement, which prohibits them from transferring detainees or internees to a partner state that is likely to subject those persons to torture or cruel, inhuman or degrading treatment or punishment. States and international organisations have sought to deal with these challenges in various international processes. In this issue of the Review, Bruce Oswald addresses these questions and discusses the intergovernmental project on the 'Handling of Detainees in International Military Operations', also known as the Copenhagen Principles, adopted on 20 October 2012. This initiative is aimed at elaborating a common approach among 22 states to ensure the humane treatment of all persons deprived of their liberty in the context of a multinational operation, and to ensure respect for IHL and IHRL during detention and transfer. The ICRC is currently conducting an extensive consultation process to enhance the protection of persons deprived of liberty in noninternational armed conflicts. ${ }^{13}$

\section{Attribution of responsibility for acts committed by multinational forces}

Finally, another challenge of multinational operations is the identification of the entity which should bear responsibility for the commission of a wrongful act committed in the course of an operation. Does responsibility lie with the state whose armed forces committed the violation, or the international organisation under whose command and control the troop-contributing state was operating, or both? As Paolo Palchetti explains in this issue of the Review, this is particularly difficult given that states usually retain a certain level of control over the troops they lend to

13 See ICRC, 'Strengthening International Humanitarian Law: Protecting Persons Deprived of Their Liberty', synthesis report from regional consultations of government experts, November 2013, available at: www. icrc.org/eng/assets/files/2013/strengthening-protection-detention-consultations-synthesis-2013-icrc.pdf. 
an international organisation, complicating the determination of the entity having control over the acts of the troops at any given point in time. Dual responsibility may be the only option for holding an entity responsible.

\section{Humanitarian engagement with multinational operations}

The interactions between humanitarian actors operating in armed conflicts and multinational forces are complex, both at the operational and policy levels. On the one hand, the presence of multinational forces may be seen as contributing to the security of humanitarian and other actors, creating a secure environment for them to deliver their services to the people in need, or escorting them when necessary. However, this may have the undesirable consequence of turning humanitarian actors accompanied by military forces into potential collateral damage from attacks targeted against the latter. The distinction between the respective roles of humanitarian actors and multinational forces is therefore crucial. The mere coexistence of humanitarians and multinational forces in the same conflict areas raises the question of coordination and civil-military integration, and the related risks of confusion in the eyes of the population and armed actors between the political, military and humanitarian agendas. It remains important to underline the necessity of preserving the essence of neutral and independent humanitarian action.

As with all parties involved in situations of conflict, the ICRC carries out bilateral dialogue with multinational forces on sensitive issues, such as allegations of violations of IHL. The complexity of this dialogue, due to the sheer multiplicity of actors involved and the global architecture of multinational operations, has prompted the ICRC to reflect on a coherent, comprehensive approach to this type of dialogue. ${ }^{14}$

For the ICRC, humanitarian engagement with multinational forces means first and foremost establishing dialogue on their rights and duties, as well as on key issues of humanitarian concern. The ICRC's dialogue with UN peacekeeping operations, for example, focuses on the protection of the civilian population, detention, demining and the conduct of hostilities, among other aspects. The ICRC also offers its services in pre-deployment briefings and dissemination sessions in the areas of deployment to troop-contributing countries. In these briefings, the role, mission and activities of the organisation are explained, and educational material

14 At the institutional level, in New York, the ICRC maintains dialogue with the UN components shaping policy on peace operations (the UN Security Council, General Assembly and Secretariat - including, among others, the Department of Peacekeeping Operations (DPKO), the Department of Department of Field Support (DFS), the Office of Legal Affairs (OLA) and the Office for the Coordination of Humanitarian Affairs (OCHA)) as well as with the troop-contributing countries and the policecontributing countries' representatives in New York. The ICRC also maintains dialogue with UN peacekeeping missions at the operational level, in the contexts where troops are deployed. When the UN works in partnership with regional and sub-regional organisations in peacekeeping missions, the ICRC strives to establish and maintain a humanitarian dialogue with those partner organisations as well. 
and IHL expertise are provided to help integrate humanitarian law and human rights norms into training and doctrine.

In light of the urgent humanitarian challenges of today's world and the everevolving mandates of multinational forces, and in view of the key role they play in international peace and security, the need to bring clarity to the roles and responsibilities of multinational forces under the law is becoming ever more pressing.

Vincent Bernard

Editor-in-Chief 